\title{
Long-term Carbon Uptake of Agro-ecosystems in the Midwest
}

Dold, C. ${ }^{1 *}$, Büyükcangaz, $\mathrm{H} .^{2}$, Rondinelli, W. ${ }^{3}$, Prueger, J.H. ${ }^{1}$, Sauer, T.J. ${ }^{1}$, Hatfield, J.L. ${ }^{1}$

1 USDA-ARS, National Laboratory for Agriculture and the Environment, Ames, IA 50011-3120, USA

2 Uludag University, Faculty of Agriculture, Biosystems Engineering Department, 16059 Bursa, Turkey

3 Former Research Technician, presently Texas A\&M University MBA program, College Station, TX

* Corresponding author email: Christian.Dold@ARS.USDA.GOV

${ }^{4}$ Mention of a specific tradename or product in this manuscript does not imply preferential treatment or endorsement by the USDA-ARS and is provided for the benefit of the reader.

\section{Abstract}

The Midwest is one of the most important production areas for corn and soybean worldwide, but also comprises remnants of natural tallgrass prairie vegetation. Future predictions suggest that corn (Zea mays L.) and soybean (Glycine max (L.) Merr.) production in the Midwest may be limited by precipitation and temperature due to climate change. Cross-biome long-term studies in situ are needed to understand carbon assimilation and impact of climate change on the entire region. In this study, we investigated the differences of gross primary production (GPP) and net ecosystem production (NEP) among typical (agro-) ecosystems of corn, soybean and tallgrass prairie from eddy flux stations from 2006 - 2015 under contrasting weather conditions. Corn had the highest annual GPP and NEP with 1305 and $327 \mathrm{~g} \mathrm{C} \mathrm{m}^{-2} \mathrm{yr}^{-1}$, while soybean had significantly lower GPP and NEP with 630 and $-34 \mathrm{~g} \mathrm{C} \mathrm{m}^{-2} \mathrm{yr}^{-1}$, excluding additional 
carbon loss by yield. Corn and soybean NEP was linear related $(p<0.05)$ to leaf area index (LAI), height or phenological stage, confirming the strong link between plant growth and ecosystem carbon balance. Tallgrass prairie had average values of GPP and NEP of 916 and $61 \mathrm{~g} \mathrm{C} \mathrm{m}^{-2} \mathrm{yr}^{-1}$, excluding loss of carbon by annual burning. Thus, prairie GPP and NEP were significantly lower than corn, but significantly higher than soybean. Probably the long fallow period on cropland, which enhanced heterotrophic respiration, and the low carbon assimilation of soybean reduced its overall carbon balance. In total, the corn-soybean agroecosystem acted as a carbon source due to carbon loss by yield removal. Values for GPP and NEP were reflected in inherent water use efficiency (IWUE*) and light use efficiency (LUE) among the agroecosystems. In addition, IWUE*, LUE or GPP of crops and tallgrass prairie were linearly related $(p<$ $0.05)$ to precipitation, volumetric soil water content (VWC) and maximum air temperature. Air temperature increased IWUE* in both, cropland and prairie vegetation. However, rainfall and VWC affected crops and prairie vegetation differently: while excessive rainfall and VWC reduced GPP or IWUE* in cropland, prairie vegetation GPP and LUE were adversely affected by reduced VWC or precipitation. Future measures of climate change adaption should consider the contrasting effects of precipitation and VWC among the different agro-ecosystems in the Midwestern USA.

Keywords: Climate change; corn; gross primary production; net ecosystem exchange; prairie; soybean

\section{Highlights}

- $\quad$ GPP and NEP was corn > prairie > soybean, excluding yield loss and burning.

- The corn-soybean agroecosystem is a carbon source including carbon loss by yield.

- High respiration in the off season and low $\mathrm{CO}_{2}$ assimilation affected soybean NEP.

- GPP, IWUE* and LUE are significantly related to maximum air temperature.

- Rain and VWC increased GPP of prairie, while it decreased GPP or IWUE* in cropland 


\section{Introduction}

In 2013 the United States produced 35\% and 32\% of the world's corn (Zea mays L.) and soybeans (Glycine $\max (\mathrm{L}$.$) Merr.), and the Midwestern United States are one of the most productive agricultural regions on$ earth (FAO, 2013). In 2012, lowa produced approximately $18 \%$ and $14 \%$ of total US corn and soybean. Corn and soybean made up about $58 \%$ and $38 \%$ of the total agricultural area in lowa, respectively (USDA, 2014). Much of the production area in the Midwest was originally covered by tallgrass prairie, where a vast land conversion in the $19^{\text {th }}$ century became one of the most rapid land transformation efforts in the history of mankind (Robertson et al., 1997; Whitney, 1994). Today remnants of the natural prairie vegetation persist (lowa: $0.1 \%$ of original extent), and re-naturalization measures are on-going (Robertson et al., 1997; Schilling and Drobney, 2014).

The intensive agricultural activity in the Midwest is also reflected in one of the highest rates of gross primary production (GPP) in the northern hemisphere during the growing season (Guanter et al., 2014). Obviously, this is due to the cultivation of corn, a $\mathrm{C}_{4}$ crop, which assimilates carbon by PEP-Carboxylase, and thus is more efficient in using light and water. In contrast, soybean as a $C_{3}$ crop is limited by atmospheric $\mathrm{CO}_{2}$, and GPP tends to be lower. The plant composition of tallgrass prairies in the Midwest consist of both, $C_{3}$ and $C_{4}$ plants, but may be dominated by the latter (Wagle et al., 2015). However, few studies have investigated the GPP of natural prairie habitats in the Midwest (e.g. Turner et al., 2003; Gilmanov et al., 2005; Joo et al., 2014; Hussain et al., 2013; Wagle et al., 2015).

In general, there remains a lack of a comprehensive understanding of cross-biome, longer-term carbon uptake. This is in spite of current well established ways to monitor daily carbon fluxes using eddy covariance technology to generate reliable and accepted in situ $\mathrm{CO}_{2}$ flux data. The limited longer term studies or meta-analysis on carbon fluxes are mainly focused on one agro-ecosystem, such as forest stands

(e.g. Grünwald and Bernhofer, 2007, Ohta et al., 2014), tallgrass prairies (e.g. Verma et al., 1989; Wagle 
et al., 2015; Petrie et al., 2016) or production areas (e.g. Gilmanov et al., 2013). Studies comparing GPP among different agro-ecosystems in the Midwest comprise short or mid-term temporal periods (Turner et al., 2003, Joo et al., 2014, Hussain et al., 2013). However, there is a compelling need to investigate a multi-year temporal period to better understand the dynamics of cropping agroecosystems. While smaller temporal windows such as an annual or two-year dataset have helped increase our understanding of extended temporal $\mathrm{CO}_{2}$ flux exchange these "shorter" periods can be easily biased by favorable or unfavorable weather conditions. In addition, we need to better understand and validate models on the effects of climatic variation on plant production and on natural habitats, which may only be achievable by long-term in-situ monitoring systems in different agroecosystems (Mekonnen et al., 2016). Thereby, the Midwestern US as one of the most important production areas is of special interest, and models now predict reduced yield by excessive spring precipitation or late summer drought conditions due to climate change (Wuebbles and Hayhoe, 2004; Ort and Long, 2014). Here we present a ten (2006 - 2015) year high resolution (15-min) eddy flux dataset from Midwestern soybean and corn production sites, in comparison to a nine year dataset $(2007-2015)$ of reconstructed tallgrass prairie in Central lowa. The objective of this study was to assess the GPP of different (agro-) ecosystems and investigate the possible drivers of carbon uptake in different land use systems over multiple years. 


\section{Material and Methods}

\subsection{Study sites}

The study sites were located on typical Midwest cropland with soybean and corn near Ames, lowa $\left(41.967^{\circ} \mathrm{N}, 93.695^{\circ} \mathrm{W}, 315\right.$ m.a.s.l), and on a reconstructed tallgrass prairie site at the Neal Smith National Wildlife Refuge in Central lowa $\left(41.558^{\circ} \mathrm{N}, 93.290^{\circ} \mathrm{W}, 270 \mathrm{~m}\right.$.a.s.I). Soils at the cropland were identified as mesic Typic Hapludolls, mesic Aquic Hapludolls, and mesic Typic Endoaquolls (Hernandez-Ramirez et al., 2010), which derived from glacial till and are influenced by the former prairie vegetation and relief (DeWitt, 1984). At the tallgrass prairie site, soils were identified as mesic Typic Argiudolls and Fine, smectitic, mesic Oxyaquic Argiudolls (Maher et al., 2010).

Table 1. Minimum air temperature $\left(T_{\min }\right)$, maximum air temperature $\left(T_{\max }\right)$, precipitation at corn, soybean and prairie sites (III $-\mathrm{XI}$ ) for the period $2006-2015$, and the 100 -year averages and $25^{\text {th }} / 75^{\text {th }}$ Quartiles of air temperature and precipitation (III - XI) of nearby weather stations.

\begin{tabular}{lllllll}
\hline Year & \multicolumn{3}{l}{ Corn \& Soybean } & \multicolumn{5}{l}{ Prairie } \\
\hline & $\mathrm{T}_{\min }\left({ }^{\circ} \mathrm{C}\right)$ & $\mathrm{T}_{\max }\left({ }^{\circ} \mathrm{C}\right)$ & Rain $(\mathrm{mm})$ & $\mathrm{T}_{\min }\left({ }^{\circ} \mathrm{C}\right)$ & $\mathrm{T}_{\max }\left({ }^{\circ} \mathrm{C}\right)$ & Rain $(\mathrm{mm})$ \\
\hline 2006 & 4.7 & 16.2 & 755 & --- & --- & --- \\
\hline 2007 & 4.0 & 14.9 & 867 & 4.9 & 16.2 & 831 \\
\hline 2008 & 2.4 & 13.2 & 1172 & 3.6 & 14.9 & 1198 \\
\hline 2009 & 2.4 & 14.4 & 979 & 3.6 & 14.7 & 1140 \\
\hline 2010 & 3.7 & 14.7 & 1293 & 4.4 & 15.3 & 1307 \\
\hline 2011 & 3.9 & 14.7 & 694 & 4.6 & 15.6 & 855 \\
\hline 2012 & 5.1 & 17.4 & 533 & 5.7 & 18.3 & 598 \\
\hline 2013 & 3.0 & 13.7 & 710 & 3.5 & 14.6 & 759 \\
\hline 2014 & 3.1 & 14.3 & 907 & 2.9 & 13.9 & 908 \\
\hline 2015 & 4.4 & 15.3 & 915 & 5.1 & 16.1 & 1013 \\
\hline Average $^{*}$ & 3.5 & 15.2 & 759 & 4.8 & 15.6 & 740 \\
\hline $25^{\text {th }}$ Quartile* & 2.9 & 14.3 & 605 & 4.1 & 14.8 & 619 \\
\hline $75^{\text {th }}$ Quartile* $^{*}$ & 4.0 & 15.9 & 865 & 5.4 & 16.3 & 861 \\
\hline
\end{tabular}

* 100-year average and quartiles from nearby weather stations (Iowa Environmental Mesonet, 2014) 


\section{Corn Soybean Production}

The cropping area comprised two neighboring fields of approximately 23 ha each, planted with corn and soybean in annual rotation (referred to as cropland hereafter). In general across the years soybeans were planted between late April and late June with harvest occurring from mid-September to mid-October, weather dependent. Corn was generally planted from mid-April to mid-May and harvested between midSeptember and early November, again weather dependent. Mean corn and soybean plant densities during the study period were approximately 84,000 and 315,000 plants ha $^{-1}$, respectively (exception: soybean 2015 with $\sim 590,000$ plants ha $^{-1}$ ). Soils on cropland are to some extent poorly drained (DeWitt, 1984), and a subsoil drainage system ameliorates negative effects of water logged soil conditions during spring. During the off-season from October/November to April/May, the cropland sites were tilled, leaving some crop residues on the bare soil surface. After the harvest, the soybean field was fertilized with anhydrous ammonia in preparation for the succeeding corn crop at a rate of $168 \mathrm{~kg} \mathrm{~N} \mathrm{ha}^{-1}$ and $\mathrm{P}_{2} \mathrm{O}_{5}$ and $\mathrm{K}_{2} \mathrm{O}$ were also applied according to soil fertility tests to provide adequate macronutrients for the crop. The corn area was cultivated in the fall to incorporate the crop residue. Both fields were lightly cultivated in the spring just prior to planting.

\section{Restored Native Prairie Grass}

The Neal Smith National Wildlife Refuge was established in 1991 in the Walnut Creek watershed on former agricultural land, oak savanna and prairie remnants with the objective to reconstruct the natural prairie vegetation prior to the era of European land reclamation. From 2005, about 1224 ha of land were planted back to tallgrass prairie, using over 200 grass and forb species (Schilling and Drobney, 2014). Dominant grass species are Poa pratensis $\left(C_{3}\right)$, Andropogon gerardii $\left(C_{4}\right)$, Sorghastrum nutans $\left(C_{4}\right)$, or Schizachyrium scoparium $\left(C_{4}\right)$ (Martin et al., 2005; Waller and Lewis, 1979). The soils are typically year-round covered 
with vegetation or plant residues, and prairie management included controlled annual (Jan, Apr)) burns of the vegetated surface.

\subsection{Eddy covariance and meteorological data}

Turbulent fluxes of carbon dioxide $\left(F_{c}\right)$, latent heat $(\lambda E)$, and sensible heat $(H)$ at each agro-ecosystem were computed using the eddy covariance (EC) method. Details of the eddy covariance approach are well described in the literature (Baldocchi et. al. 1988; Verma, 1990; Kaimal and Finnigan, 1994; Lee et al. 2004; Burba, 2013). Briefly each EC station was equipped with a high frequency open path infrared gas analyzer (IRGA, LI-7500, LICOR Biosciences Inc., Lincoln, NE, USA ${ }^{4}$ ) that measures water vapor $\left(\rho_{w}\right)$ and carbon dioxide $\left(\rho_{c}\right)$ densities. High frequency instantaneous wind speed velocity components were measured with a 3-D sonic anemometer (CSAT, Campbell Scientific, Inc., Logan, UT, USA). The 3-D sonic anemometer uses three pairs of ultrasonic transmit/receive transducers to measure the transit time of acoustic signals traveling between the transducer pairs. The difference in transit times is used to compute instantaneous wind speed velocities along each transducer axis in three dimensions, which are then transformed into orthogonal wind components $\left(u, v\right.$ and $w$ in $\left.\mathrm{m} \mathrm{s}^{-1}\right)$. The sonic temperature $\left(T_{s}\right)$ is computed from the speed of sound determined from the average transit time and the distance between the transducers.

The $F_{c}, \lambda E$, and $H$ fluxes were computed as the covariance between the instantaneous vertical wind velocity $\left(w^{\prime}\right)$ and $\rho_{c}$, water vapor density $\left(q^{\prime}\right)$ and $T_{s}$, respectively. The turbulent fluxes were coordinate rotated (Tanner and Thurtell, 1969) and corrected for variations in temperature and air density based on the Webb-Pearman-Leuning algorithm (Webb et al., 1980) as well as sensor separation following Moore (1986). Operation and placement of these energy balance systems is described in Hernandez-Ramirez et al. (2011). 
All EC stations were instrumented with a 4-component net radiometer (CNR-1, Kipp \& Zonen, Delft, The Netherlands) positioned over the canopy at a nominal distance away from the flux tower to avoid any interference of the incoming/outgoing shortwave and longwave radiation. An air temperature and relative humidity probe (Vaisala HMP45c, Campbell Scientific Inc., Logan, UT) recorded air temperature, saturation vapor density and relative humidity. Soil heat flux plates (HFT-1, Radiation Energy Balance, Seattle, WA) were placed $8 \mathrm{~cm}$ below the soil surface. A soil moisture sensor (Hydra Probe, Stevens Water Monitoring Systems, Portland, OR, USA) to record volumetric water content (VWC) at $10 \mathrm{~cm}$ soil depth, and soil temperature thermocouples at 2 and $6 \mathrm{~cm}$ below the soil surface were used to compute the heat storage component of the layer of soil above the soil heat flux plate (Hanks and Ashcroft, 1980; Klute, 1986). Precipitation (March - November) was recorded in hourly (2007 and 2008 on cropland) and 15minute intervals using tipping buckets. Rainfall data were averaged for each site. Air temperature and rainfall differed substantially among years, and are summarized in Table 1.

Eddy covariance data were acquired from the three stations from 2006 to 2015 . The EC sampling rate (high frequency) was $10 \mathrm{~Hz}$ from 2006 - 2011 and $20 \mathrm{~Hz}$ from 2012 - 2015. The change in sampling frequency (from $10-20 \mathrm{~Hz}$ ) was made to more closely match the AmeriFlux network sampling frequencies (http://ameriflux.ornl.gov). The remaining slow response instrumentation was all sampled at $0.1 \mathrm{~Hz}(10$ sec) on an averaged 15-minute interval. Signals from all EC instrumentation were recorded on data loggers (CR5000, Campbell Scientific, Logan, UT).

\subsection{Data screening and interpolation}

The datasets were screened for sensor failures and statistical outliers and subsequently interpolated (gap filled) between existing data. If one data point of a certain variable at a certain time interval was excluded 
from further analysis, all inter-dependent variables were also not considered (e.g. friction velocity $\mathrm{u}^{*}$-> $\lambda \mathrm{E}$-> evapotranspiration ET).

Initially all data, that violated empirically set limits (e.g $\mathrm{F}_{\mathrm{c}}-5$ to $10 \mathrm{mg} \mathrm{CO}_{2} \mathrm{~m}^{-2} \mathrm{~s}^{-1}$ ), were excluded from further analysis (Hernandez et al., 2011). Further screening included periods of precipitation (Hernandez et al., 2011), possible water condensation ( $\mathrm{rH}>98 \%$ ) on the instruments (Baker and Griffis, 2005), during low wind turbulences $\left(\mathrm{u}^{*}<0.075 \mathrm{~m} \mathrm{~s}^{-1}\right)$ and a wind directions opposite to the sensor head directions (Hernandez et al., 2010), and when flagged by the manufacturer's internal IRGA and CSAT warning systems (e.g. during storm events). We also used the water vapor saturation measurement from the humidity probe to screen $\lambda \mathrm{E}$, since the humidity sensor is not affected by dust or rainfall events. Water vapor saturation was compared with the corresponding IRGA measurement (Schmidt et al., 2012), and an empirically derived difference of $10 \mathrm{~g} \mathrm{~cm}^{-3}$ water vapor density between both sensors was used as a threshold level.

Carbon dioxide fluxes were divided into day and nighttime subsets $\left(F_{c \text { day, }} F_{c \text { night }}\right)$, where nighttime was defined as periods when the mean incoming shortwave radiation $<20 \mathrm{~W} \mathrm{~m}^{-2}$, which was additionally crosschecked against the time of sunrise and sunset (Reichstein et al., 2005). Thereafter, $F_{c}$ night was checked for outliers by clustering the data into subgroups of the same nighttime hours. Data were considered as outliers when values exceeded an empirically derived upper and lower boundary within each subgroup. In addition, $\mathrm{F}_{\mathrm{c} \text { night }}<0.2 \mathrm{mg} \mathrm{CO}_{2} \mathrm{~m}^{-2} \mathrm{~s}^{-1}$ was excluded as outlier. The daytime $\mathrm{CO}_{2}$ flux $\mathrm{F}_{\mathrm{c} \text { day }}$ was outlier screened along a (1) monthly and (2) daily basis, similar to the approach of Vickers and Mahrt (1997) but using the interquartile range (IQR) procedure where outliers were defined as $1^{\text {st }} / 3^{\text {rd }}$ Quartile \pm $z$ * IQR (where $z=3.5$ for the monthly, and 1.5 for the daily time basis).

Air temperature, saturation vapor density and shortwave radiation were also screened using the IQR approach ( 1 month moving window before and after the screened 15 minute interval, and $z=3.5$ ). 
Thereafter, the 15-minute dataset (without $F_{c}$ ) was interpolated (or gap filled) following an inverse weighted time average procedure (Hernandez et al., 2010):

$\mathrm{y}=\frac{\sum_{i=1}^{n} v_{i} / t_{i}^{2}}{\sum_{i=1}^{n} 1 / t_{i}^{2}}$

where: $y=$ gap filled variable, $v_{i}=$ neighboring 15 -minute data point (from $i$ to $n$ ), $n=$ maximum number of neighboring data points included in the calculation, and $t_{i}$ is the time period (in minutes) between the missing data point $\mathrm{y}$ and its neighboring value $\mathrm{v}_{\mathrm{i}}$.

The minimum and maximum number of data points included to calculate a new gap filled value was $n=8$ and 24 , respectively, i.e. a maximum of twelve 15-minute data points or a three hour interval prior and after the missing data point $y$.

In the case of a two-month gap (mid-May to beginning July 2009 in corn) in the air temperature dataset, the data from the adjacent soybean field was included for further calculations.

Prior to the application of Eq (1), $\mathrm{F}_{\mathrm{c} \text { night }}$ was gap filled using the relation between air temperature and $\mathrm{CO}_{2}$ fluxes on a monthly time basis (Lloyd and Taylor, 1994; Reichstein et al., 2005):

$\mathrm{F}_{\mathrm{c} \text { night }}=\mathrm{R}_{\mathrm{ref}} * \exp \left(\mathrm{E}_{0} *\left[1 /\left(\mathrm{T}_{\mathrm{ref}}-\mathrm{T}_{0}\right)-1 /\left(\mathrm{T}_{\mathrm{air}}-\mathrm{T}_{0}\right)\right]\right)$

where: $F_{c}$ night $=$ nighttime $\mathrm{CO}_{2}$ flux $\left(\mathrm{mg} \mathrm{m}^{-2} \mathrm{~s}^{-1}\right), \mathrm{R}_{\text {ref }}=$ reference nighttime $\mathrm{CO}_{2}$ respiration, independent from temperature $\left(\mathrm{mg} \mathrm{m}^{-2} \mathrm{~s}^{-1}\right) ; \mathrm{E}_{0}=$ activation energy $(\mathrm{K}) ; \mathrm{T}_{\text {ref }}=$ reference temperature (here set to $\left.10^{\circ} \mathrm{C}\right)$, $\mathrm{T}_{0}=$ base temperature (here set to $\left.-46.02^{\circ} \mathrm{C}\right), \mathrm{T}_{\text {air }}=$ measured air temperature $\left({ }^{\circ} \mathrm{C}\right)$.

The sign convention was positive for $\mathrm{CO}_{2}$ fluxes from the soil to the atmosphere. Missing values of $\mathrm{F}_{\mathrm{c} \text { night }}$ were only gap filled with $\mathrm{Eq}(2)$, when the standard error of $\mathrm{E}_{0}$ of the monthly derived models was $<50 \%$ (Reichstein et al., 2005). 
$F_{c \text { day }}$ was gap filled using the relation between PAR and daytime $\mathrm{CO}_{2}$ fluxes (Eq (3), chapter 2.4). Missing values of $F_{c}$ day were only gap filled, when Eq (3) was significant at $p<0.05$. Thereafter, $F_{c}$ night and $F_{c}$ day were gap filled using Eq (1).

After the gap filling procedure the whole dataset was divided into day- and nighttime subsets. Further analysis included datasets that had more than $80 \%$ of 15 minute intervals per day-/nighttime (Hernandez et al., 2010) which became the basis for calculating daily means, sums, minima or maxima. The daily datasets were then again gap filled using Eq. (1), where $v_{i}$ is a daily neighbored data point, $t_{i}$ is the daily period between $\mathrm{v}_{\mathrm{i}}$ and $\mathrm{y}$ and maximum $\mathrm{n}$ comprises 12 days prior and after the missing daily data point. The validation of the various $F_{c}$ gap filling techniques, and the amount of $F_{c}$ outlier screened and gap filled is presented in Appendix A.

\subsection{Daytime respiration}

Daytime respiration ( $R_{\text {day }}$ ) for the growing seasons was calculated as the sum of carbon assimilated by plants that exceeded the ecosystem respiration ( $\left.R_{\text {eco }}\right)$. During the non-growing season $R_{\text {day }}$ equals $F_{c}$ day. $R_{\text {day }}$ was derived from the non-linear relationship between PAR and $F_{c \text { day }}$ using a rectangular hyperbola function (Gilmanov et al., 2007):

$F_{c \text { day }}=\left(\left(A Q Y * P A R^{*} P_{g \text { max }}\right) /\left(P_{g \text { max }}+A Q Y * P A R_{I N}\right)\right)-R_{\text {day }}$

where: $\mathrm{F}_{\mathrm{c} \text { day }}=$ daytime $\mathrm{CO}_{2}$ flux $\left(\mu \mathrm{mol} \mathrm{m} \mathrm{m}^{-2} \mathrm{~s}^{-1}\right) ; \mathrm{AQY}=$ apparent quantum yield $\left(\mu \mathrm{mol} \mathrm{CO}_{2} \mu \mathrm{mol} \mathrm{PAR}^{-1}\right), \mathrm{Pg}_{\mathrm{g}}$ $\max =$ maximum gross photosynthesis rate $\left(\mu \mathrm{mol} \mathrm{CO}_{2} \mathrm{~m}^{-2} \mathrm{~s}^{-1}\right) ; \mathrm{PAR}_{\mathrm{IN}}=$ Incoming photosynthetic active radiation $\left(\mu \mathrm{mol} \mathrm{m} \mathrm{m}^{-2} \mathrm{~s}^{-1}\right) ; \mathrm{R}_{\text {day }}=$ mean daytime respiration $\left(\mu \mathrm{mol} \mathrm{CO}_{2} \mathrm{~m}^{-2} \mathrm{~s}^{-1}\right)$.

The upper and lower boundaries of the parameters $A Q Y, P_{g} \max$ and $R_{\text {day }}$ were defined according to sitespecific conditions, or from values in literature (Lobo et al., 2013) (Table A2). Photosynthetic active 
radiation was derived using incoming shortwave radiation, and assuming that $1 \mathrm{~W} \mathrm{~m}^{-2}$ equals $4.6 \mu \mathrm{mol} \mathrm{m}-$ ${ }^{2} \mathrm{~s}^{-1}$ (Campbell and Norman, 1998), and that $45 \%$ of incoming shortwave radiation is the photosynthetic active radiation (Meek et al., 1984; Schmidt et al., 2012). $R_{\text {day }}$ was only used when the model was significant at $\mathrm{p}<0.05$. $\mathrm{R}_{\text {day }}$ was then converted to $\mathrm{g} \mathrm{C} \mathrm{m}^{-2} 15 \mathrm{~min}^{-1}$, and multiplied by the number of 15 minute daytime time intervals per day to derive daily daytime respiration $R_{\text {day }}\left(\mathrm{g} \mathrm{C} \mathrm{m}^{-2} \mathrm{~d}^{-1}\right)$. Thereafter, $R_{\text {day }}$ was gap filled using Eq (1).

\subsection{Gross primary production and Net ecosystem production}

Despite the various efforts of gap filling, there were still data missing in the 15 minute and daily datasets (Table A.1). Hence, daily $F_{c}$ was calculated as (Roxbergh et al., 2005):

$\mathrm{F}_{\mathrm{c} \text { day/night }}=\overline{\mathrm{F}}_{\mathrm{c} 15 \min } * \mathrm{n}_{15 \min }$

where: $F_{c \text { day/night }}=$ daily sum of $\mathrm{CO}_{2}$ daytime or nighttime flux $\left(\mathrm{mg} \mathrm{CO}_{2} \mathrm{~m}^{-2} \mathrm{~d}^{-1}\right), \bar{F}_{\mathrm{c} 15 \text { min }}=$ daily 15 minute daytime or nighttime $\mathrm{CO}_{2}$ flux average $\left(\mathrm{mg} \mathrm{CO}_{2} \mathrm{~m}^{-2} 15 \mathrm{~min}^{-1}\right), \mathrm{n}_{15 \min }=$ number of daytime or nighttime 15 minute intervals per day.

The $\mathrm{CO}_{2}$ flux was converted to the carbon (C) equivalent, and the net ecosystem production (NEP), the ecosystem respiration $\left(\mathrm{R}_{\mathrm{eco}}\right)$ and the gross primary production (GPP) were computed as:

$N E P_{d}=F_{c \text { day }}+F_{c \text { night }}$

$R_{\text {ecod }}=R_{\text {day }}+F_{c \text { night }}$

$\mathrm{GPP}_{d}=\mathrm{NEP}_{d}-\mathrm{R}_{\text {ecod }}$

where: NEP $=$ daily net ecosystem production $\left(\mathrm{g} \mathrm{C} \mathrm{m}^{-2} \mathrm{~d}^{-1}\right), \mathrm{Reco} \mathrm{d}_{\mathrm{d}}=$ daily ecosystem respiration $\left(\mathrm{g} \mathrm{C}^{-2} \mathrm{~d}^{-}\right.$ $\left.{ }^{1}\right), \mathrm{GPP}_{\mathrm{d}}=$ daily gross primary production $\left(\mathrm{g} \mathrm{C} \mathrm{m}^{-2} \mathrm{~d}^{-1}\right), \mathrm{F}_{\mathrm{c} \text { day }}=$ daily sum of daytime carbon flux $\left(\mathrm{g} \mathrm{C} \mathrm{m}^{-2} \mathrm{~d}^{-}\right.$ 
$\left.{ }^{1}\right), F_{c}$ night $=$ daily sum of nighttime carbon flux (i.e. nighttime respiration) $\left(\mathrm{g} \mathrm{C} \mathrm{m}^{-2} \mathrm{~d}^{-1}\right), R_{\text {day }}=$ daytime respiration, either from $F_{c \text { day }}$ (during the off season) or calculated with Eq. (3) ( $\mathrm{g} \mathrm{C} \mathrm{m}^{-2} \mathrm{~d}^{-1}$ ).

Note that the arithmetic sign convention is negative for fluxes from the surface to the atmosphere, and that NEP can be less than zero. The annual sums of NEP and GPP were computed as:

NEP $=\Sigma N E P_{d} / d^{*} n_{\text {year }}$

$R_{\text {eco }}=\Sigma R_{\text {eco d }} / d * n_{\text {year }}$

$\mathrm{GPP}=\Sigma \mathrm{GPP}_{\mathrm{d}} / \mathrm{d} * \mathrm{n}_{\text {year }}$

where: $d=$ number of measured or gap filled days, $n_{\text {year }}=$ number of days per year.

\subsection{Light and water use efficiency}

Light use efficiency was computed following Jenkins et al. (2006):

$L U E=G P P /\left(P A R_{I N}-P A R_{O U T}\right)$

where: $L U E=$ daily light use efficiency $\left(\mathrm{g} \mathrm{C} \mathrm{MJ}^{-1}\right), \mathrm{PAR}_{\mathrm{IN}}=$ incoming photosynthetic active radiation $\left(\mathrm{MJ} \mathrm{m}^{-}\right.$

$\left.{ }^{2} \mathrm{~d}^{-1}\right) ;$ PARout $=$ outgoing photosynthetic active radiation $\left(\mathrm{MJ} \mathrm{m}^{-2} \mathrm{~d}^{-1}\right) ; \mathrm{GPP}=$ gross primary production $(\mathrm{g} \mathrm{C}$ $\left.m^{-2} d^{-1}\right)$

Water use efficiency was computed following Beer et al. (2009):

$\mathrm{IWUE}^{*}=\mathrm{GPP} * \mathrm{VPD} / \mathrm{ET}$

where: IWUE* = daily inherent water use efficiency $\left(\mathrm{g} \mathrm{C}^{*} \mathrm{hPa} \mathrm{kg}^{-1} \mathrm{H}_{2} \mathrm{O}\right), \mathrm{GPP}=$ Gross primary production $\left(\mathrm{g} \mathrm{C} \mathrm{m}^{-2} \mathrm{~d}^{-1}\right) ; \mathrm{VPD}=$ daily daytime vapor pressure deficit $(\mathrm{hPa}), \mathrm{ET}=$ daytime evapotranspiration $(\mathrm{mm}=\mathrm{kg}$ $\left.\mathrm{m}^{-2} \mathrm{H}_{2} \mathrm{O}\right)$. 
VPD was calculated following the approach of Allen et al. (1998), using daily daytime minimum and maximum air temperature and relative humidity. ET was calculated as the quotient between latent heat flux $\left(\lambda E, W ~ m^{-2}\right)$ and the latent heat of vaporization $(\lambda)$, of which the latter was calculated as a function of mean air temperature (Allen and Pruitt, 1991).

ET comprises both, plant transpiration and soil water evaporation, of which the latter is not connected to GPP. Soil water evaporation increases ET especially after rain events, which results in an underestimation of IWUE*. Therefore, rainy days and two subsequent days after a rain event were excluded from IWUE* calculation to diminish the impact of soil water evaporation (Beer et al., 2009, Hussain et al., 2011).

The possible decoupling of the crop and prairie canopy to the atmosphere was evaluated with linear regression analysis using GPP*VPD as the dependent and ET as the independent variables (Beer et al., 2009). Although, the relationship was best explained with a linear model, one can see a non-linear trend, especially in tallgrass prairie (Fig. B.1), thus showing a possible decoupling of the herbaceous canopy to the atmosphere (i.e. possible over- or underestimation of VPD and hence IWUE*) (Beer et al., 2009; Wagle et al., 2015). In addition, the linear model could only explain $31 \%$ to $63 \%$ of the data variation.

\subsection{Crop growth and yield}

Phenological stages (vegetative and reproductive growth categorized as V and R Stages, respectively) and height of corn and soybean were measured each year except 2007. Leaf area index (LAI) of both crops was measured with LAI-2200 (LICOR Biosciences Inc., Lincoln, NE, USA) from 2010 - 2015. Measurements of LAI and phenological stages were conducted at weekly or monthly intervals throughout the growing season. 
Crop height was measured from the ground to the top of the canopy, and plotted against time (day of the year, DOY) using a three parameter logistic model (Evans et al., 2009):

$H=H_{\max } /\left(1+\exp \left(-\left(\right.\right.\right.$ DOY $\left.\left.\left.-x_{0}\right) / b\right)\right)$

where: $\mathrm{H}=$ crop height $(\mathrm{cm}) ; \mathrm{H}_{\max }=$ maximum height $(\mathrm{cm}) ; \mathrm{b}$ and $\mathrm{x}_{0}$ are constants.

Yield data of corn and soybean from 2006 - 2014 was recorded, and dry grain and seed yield was estimated assuming a moisture content of $15.5 \%$ and $13 \%$ for corn and soybean, respectively. The carbon lost by harvest was then calculated using a grain and seed carbon content of $44.8 \%$ and $51.1 \%$ for corn and soybean, respectively (Hernandez et al., 2011).

\subsection{Data preparation and statistical analysis}

Datasets were separated between growing season (GS) and off season (OS). The annual dataset will be referred to as total season (TS). The growing season was determined either as the time period between date of planting and date of harvest (corn and soybean), or by the days with mean temperature $>5{ }^{\circ} \mathrm{C}$ (prairie). Mean GS was $173 \pm 19,142 \pm 16$ and $242 \pm 12$ days for the corn, soybean and prairie site, respectively.

Annual sums of GPP and NEP were analyzed for statistical differences between means by One-way ANOVA with repeated measures, with site (corn, soybean, and prairie) as between subject and Year (2006 - 2015) as within subject factor. The groups were separated with the Holm-Sidak Post-hoc test. Prior to analysis, GPP and NEP were transformed using a cube root to meet homoscedasticity.

The relationship of daily NEP to plant production parameters (phenological stages, $H_{\max }$, LAI) were statistically evaluated $(p<0.05)$ with linear regression or Spearman rank order correlation. Relations between NEP, Reco, GPP, IWUE* and LUE to environmental data ( $T_{\max }$, rain, or VWC) was analyzed with 
Pearson correlation or regression analysis $(p<0.05)$. Prior to that, outliers in the IWUE* and LUE dataset were identified by setting an empirical, site-specific upper boundary. All statistical analyses were performed with the Sigmaplot 11 software package.

((Figure 1; single column)) 


\section{Results}

The $\mathrm{CO}_{2}$ flux $\mathrm{F}_{\mathrm{c}}$ showed substantial differences within the year and among sites. Comprising the whole nine and ten-year dataset, net assimilation (positive $F_{c}$ ) exceeded nighttime respiration (negative $F_{c}$ ) from June to September in corn, from July to September in soybean, and from May to August in tallgrass prairie. Maximum net carbon assimilation and nighttime respiration occurred during July and August in corn with -0.46 to 2.05 and -0.54 to $1.92 \mathrm{mg} \mathrm{CO}_{2} \mathrm{~m}^{-2} \mathrm{~s}^{-1}$, respectively. In soybean, maximum net carbon assimilation and nighttime respiration was also reached in July and August with -0.42 to 0.98 and -0.39 to $1.09 \mathrm{mg} \mathrm{CO}_{2}$ $\mathrm{m}^{-2} \mathrm{~s}^{-1}$, respectively (exception: soybean 2013 with peaks in August and September). Highest $\mathrm{F}_{\mathrm{c}}$ flux at the prairie site was in June and July with -0.38 to 0.80 and -0.42 to $0.80 \mathrm{~g} \mathrm{CO}_{2} \mathrm{~m}^{-2} \mathrm{~s}^{-1}$ (exception: 2012 with peaks in May and June) (Fig. 1).

Derived GPP and NEP values were significantly different among sites; on an annual basis, and for the sub periods of GS and OS. Average GPP was 1305, 630 and $916 \mathrm{~g} \mathrm{C} \mathrm{m}^{-2} \mathrm{yr}^{-1}$ for the corn, soybean and prairie site, respectively. Corn GPP was significantly higher, followed by prairie, and soybean GPP was significantly lower (Fig. 2). Average ( \pm SD) GPP in July (as a peak month at most site-years) was $18.1 \pm 5.0,7.8 \pm 3.7$ and $7.6 \pm 2.2 \mathrm{~g} \mathrm{C} \mathrm{m}^{-2} \mathrm{~d}^{-1}$ for corn, soybean and prairie, respectively. There was no assimilation of carbon during OS, and hence GS GPP equals TS GPP (Fig. 3).

Average TS NEP was 327, -34 , and $61 \mathrm{~g} \mathrm{C} \mathrm{m}^{-2} \mathrm{yr}^{-1}$ for corn, soybean and prairie, respectively. Corn NEP was significantly higher than soybean and prairie NEP, with soybean NEP being the lowest. Considering only the sub period GS, corn NEP was significantly higher than at all other sites, while prairie and soybean NEP were not significantly different (Fig. 2). Average NEP in July was $9.1 \pm 3.9,2.6 \pm 2.6$ and $2.2 \pm 2.0 \mathrm{~g} \mathrm{C} \mathrm{m}^{-2} \mathrm{~d}^{-}$ ${ }^{1}$ for corn, soybean and prairie, respectively (Fig. 3). 


\section{((Figure 2; single column))}

There was no assimilation of carbon during OS, and hence OS NEP equals OS Reco, with $-14,-105$ and -150 $\mathrm{g} \mathrm{C} \mathrm{m}^{-2} \mathrm{yr}^{-1}$ for prairie, corn and soybean, respectively. Thereby, OS $\mathrm{R}_{\mathrm{eco}}$ at the prairie site was significantly higher, followed by corn, and soybean Reco was significantly lower. The GS Reco significantly decreased among sites in the order corn > prairie > soybean with $-862,-792$ and $-546 \mathrm{~g} \mathrm{C} \mathrm{m}^{-2} \mathrm{yr}^{-1}$, respectively (Fig. 2). The TS Reco was significantly higher for corn, followed by prairie, and was significantly lower for soybean (Table 2). Average $R_{\text {eco }}$ in July was $-9.0 \pm 2.6,-5.2 \pm 2.0$ and $-5.5 \pm 1.5 \mathrm{~g} \mathrm{C} \mathrm{m}^{-2} \mathrm{~d}^{-1}$ for corn, soybean and prairie, respectively (Fig. 3).

The analysis does not include the loss of carbon by harvest from the corn-soybean rotation. Average ( \pm SD) carbon stored in corn grain and soybean seeds made up $492 \pm 42$ and $182 \pm 12 \mathrm{~g} \mathrm{C} \mathrm{m}^{-2} \mathrm{yr}^{-1}$, respectively. Thus, GS NEP of corn and soybean reduces to $-170 \pm 71$ and $-239 \pm 64 \mathrm{~g} \mathrm{C} \mathrm{m}^{-2} \mathrm{yr}^{-1}$ from $2006-2014$. The loss of carbon on prairie by burning could not be reliably quantified.

The increase and decline of GPP and NEP was related to plant growth. Carbon assimilation of corn exceeded ecosystem respiration at DAP 36 and development stage $\sim \mathrm{V} 5$. At that time cumulative daily corn NEP was at its minimum of $-116 \mathrm{~g} \mathrm{C} \mathrm{m}^{-2} \mathrm{yr}^{-1}$. Highest NEP rates were attained from DAP 63 ( V11 - 12) with $\sim 10-11 \mathrm{~g} \mathrm{C} \mathrm{m}^{-2} \mathrm{~d}^{-1}$, and cumulative NEP increased above zero. Thereafter, cumulative NEP reached a 'plateau phase' with $\sim 225 \mathrm{~g} \mathrm{C} \mathrm{m}^{-2} \mathrm{yr}^{-1}$ from DAP 129 - 143 ( R5-6), and ecosystem respiration exceeded carbon assimilation of the crop. Eventually, cumulative NEP declined to $\sim 320 \mathrm{~g} \mathrm{C} \mathrm{m}^{-2} \mathrm{yr}^{-1}$ at the end of the growing season (Fig. 4 A, C). Carbon assimilation of soybean exceeded ecosystem respiration at DAP 42, which corresponds to $\mathrm{V} 4 \mathrm{R} 1$, and cumulative NEP was at its minimum of $-170 \mathrm{~g} \mathrm{C} \mathrm{m}^{-2} \mathrm{yr}^{-1}$. Highest NEP rates were reached at DAP $72($ V12 - $14 \mathrm{R} 3-4)$ with $\sim 4.5 \mathrm{~g} \mathrm{C} \mathrm{m}^{-2} \mathrm{~d}^{-1}$. However, cumulative NEP increased above zero at DAP 103 ( V20 R5-6), when NEP rates were already declining. Highest cumulative NEP of $\sim 35 \mathrm{~g} \mathrm{C} \mathrm{m}^{-2} \mathrm{yr}^{-1}$ was attained at DAP 135 (R6 - 7), and thenceforth ecosystem respiration exceeded carbon 
assimilation. Eventually, cumulative NEP decreased to approximately $-70 \mathrm{~g} \mathrm{C} \mathrm{m}^{-2} \mathrm{yr}^{-1}$ (senescence and leaf abscission) (Fig. 4 B, D).

There was a significant positive correlation between V-Stage and NEP, and a significant negative correlation between R-Stage and NEP in corn. In soybean, there was a significant positive correlation between V-Stage 1 - 14, R-Stage 1 -5 and NEP, and a significant negative correlation between V Stage 15 - 20 and R-Stage $6-8$ and NEP (Fig. 3 C, D). In addition, there was a significant linear relationship between LAI and NEP during both, vegetative (V-Stage) and regenerative (R-Stage) plant growth of corn, explaining about $57 \%$ and $44 \%$ of the data variation. There was also a significant linear relationship between LAI and NEP in soybean, explaining $52 \%$ (until R5) and $36 \%$ (from R6) of the data variation (Fig. 4 E, F). Furthermore, there was a significant linear relationship between maximum height $\mathrm{H}_{\max }$ and NEP in corn and soybean, explaining $53 \%$ and $62 \%$ of the data variation (Fig. 5).

Differences of GPP and NEP among sites were related to water and light use efficiency. The average ( \pm SD) IWUE* during July was $48.5 \pm 12.0,22.3 \pm 7.9$ and $25.3 \pm 7.3 \mathrm{~g} \mathrm{C}^{*} \mathrm{hPa} \mathrm{kg} \mathrm{H}_{2} \mathrm{O}^{-1}$ for corn, soybean and prairie vegetation, respectively (Fig. 6 A-C). The average LUE ( \pm SD) for the same period was $2.3 \pm 0.6,1.1$ \pm 0.5 and $1.0 \pm 0.4 \mathrm{~g} \mathrm{C} \mathrm{MJ}^{-1}$ for corn, soybean and prairie (Fig. $6 \mathrm{D}-\mathrm{F}$ ). Corn, soybean and prairie GPP, IWUE* and LUE were significantly positively related to $T_{\max }$ (Fig. 7). Monthly GS NEP was positively correlated to $T_{\max }$, while monthly GS Reco was negatively correlated to $T_{\max }$ in corn, soybean and prairie (Table 2 ). In addition, corn soybean and prairie GPP, IWUE* and LUE were significantly related to either precipitation (Fig. 8) or VWC (Fig. 9). GS NEP was negatively correlated to rain and VWC in corn and soybean, while it was positively correlated to VWC in prairie. GS Reco was not affected by rainfall or VWC in corn and soybean, while it was negatively correlated in tallgrass prairie (Table 2 ).

Table 2. Pearson correlation between GS NEP and Reco versus precipitation ( $n=10 / 10 / 9)$, VWC ( $n=$ $10 / 10 / 9)$ and $T_{\max }(n=42 / 37 / 71)$ for corn, soybean and prairie (excluding days with GPP $<0.1 \mathrm{~g} \mathrm{C} \mathrm{m}^{-2} \mathrm{~d}^{-1}$ ) Site $\quad \mathrm{NEP} / \mathrm{R}_{\mathrm{eco}}\left(\mathrm{g} \mathrm{C} \mathrm{m}^{-2} \mathrm{yr}^{-1}\right) \quad$ Rain $(\mathrm{mm}) \quad \mathrm{VWC}\left(\mathrm{m}^{3} \mathrm{~m}^{-3}\right) \quad \mathrm{T}_{\max }\left({ }^{\circ} \mathrm{C}\right)$ 


\begin{tabular}{|c|c|c|c|c|}
\hline \multirow[t]{2}{*}{ Corn } & NEP & $-0.58^{*}$ & $-0.57^{*}$ & $0.71^{\star * *}$ \\
\hline & $\mathrm{R}_{\text {eco }}$ & ns & ns & $-0.65^{\star * \star}$ \\
\hline \multirow[t]{2}{*}{ Soybean } & NEP & $-0.61^{*}$ & $-0.69^{\star *}$ & $0.41^{* \star *}$ \\
\hline & $\mathrm{R}_{\text {eco }}$ & ns & ns & $-0.49^{\star \star \star}$ \\
\hline \multirow[t]{2}{*}{ Prairie } & NEP & ns & $0.64^{*}$ & $0.54^{\star \star *}$ \\
\hline & $\mathrm{R}_{\mathrm{eco}}$ & $-0.59^{*}$ & ns & $-0.91^{* \star *}$ \\
\hline
\end{tabular}

$* \mathrm{p}<0.1, * * \mathrm{p}<0.05, * * * \mathrm{p}<0.01$

\section{Discussion}

\subsection{Differences of GPP, NEP and Reco among agro-ecosystems}

The amount of carbon assimilated (GPP), stored (NEP) and respired ( $\left.R_{\text {eco }}\right)$ among three Midwestern agroecosystems was investigated in this study. Thereby, $F_{c}$, GPP, NEP and $R_{\text {eco }}$ were within the range of several Midwestern corn (Gilmanov et al., 2013), soybean (Gilmanov et al., 2014), and tallgrass prairie sites (Verma et al., 1989; Wagle et al., 2015) (Table 2). In comparison to other Midwest cropping areas (Gilmanov et al., 2013; Gilmanov et al., 2014), GPP, NEP and Reco of corn was higher, while soybean carbon assimilation was lower than the average. Prairie GPP was also low, while NEP was highest compared to other tallgrass prairie vegetation sites, suggesting a lower ecosystem respiration in this study. In general, between-site variation in the Midwest is linked to climatic differences, and in the case of cropland to the type and intensity of crop management (Wagle et al., 2015; Petrie et al., 2016; Hernandez et al., 2011; Gilmanov et al., 2013, Chi et al., 2016). How management decisions can affect the carbon balance can be seen in 2015. In that year, plant growth was stunted, which was reflected in the lowest $H_{\max }$ (Fig. 4), and was probably connected to incorrect herbicide application. The impact was so severe that soybean GS NEP was negative; meaning that overall carbon assimilation in the GS could not compensate carbon respiration losses from soil, plant and residues. 
Corn GPP, NEP and Reco significantly exceeded all other agro-ecosystems during TS, GS or OS in the observed ten year period (Table 2), and excluding the loss of carbon by harvest removal. That is in agreement with previous studies, where corn GPP surpassed tallgrass prairie GPP (Turner et al., 2003), soybean GPP and NEP (Gilmanov et al., 2013, Gilmanov et al., 2014; Hernandez et al., 2011), respectively. The high values of corn $\mathrm{R}_{\text {eco }}$ during $\mathrm{OS}$ are probably the result of tillage activities after harvest and higher amounts of remaining corn residues, both leading to higher soil respiration (Hernandez et al., 2011).

Interestingly, GPP, TS NEP and TS Reco of prairie vegetation were higher than soybean and lower than corn (Table 2). That is atypical in the Midwest region, where cropland is considered to be a carbon sink, while grasslands are a carbon source (Lu and Zhuang, 2010). Soybean NEP was not different to prairie NEP during the GS, but that was outcompeted by a significantly lower prairie $R_{\text {eco }}$ during OS. Probably, respiration in tallgrass prairie during the OS was suppressed by a constant vegetation cover, and no soil disturbance. As described above, probably tillage activities and bare soil lead to high soil respiration on cropland (e.g. Hernandez et al., 2011), and a better management of the agricultural sites during the OS may ameliorate the annual carbon balance. In addition, the OS was much shorter in tallgrass prairie: while the cornsoybean cropland assimilated high amounts of carbon during a considerably short period of time, the prairie vegetation took up smaller amounts of carbon in a longer time period (Fig. 1). The cropland carbon uptake was restricted to the time of plant emergence to harvest of one crop, since no double crop system was used or cover crops planted. Probably the abundance (early and late growing species) and species composition (dominant $C_{3}$ versus $C_{4}$ plants) influenced the amount and length of prairie carbon assimilation (Martin et al., 2005).

It should be noted, that the loss of carbon by yield decreased NEP substantially, showing that the cornsoybean rotation system functions as a carbon source. That is partly in accordance with Hernandez et al. (2011) who found near-neutral and negative carbon budget in corn and soybean years, respectively. At 
the same time, it was not feasible to estimate the loss of carbon on prairie by fire, because $F_{c}$ data was not reliable and we lack information of carbon stored in the biomass at that site. A full carbon balance is thus beyond the scope of this study. Yet, the tallgrass prairie assimilated and stored more carbon than soybean and less than corn, because of the poor carbon assimilation of soybean and the long fallow periods with high heterotrophic respiration.

\subsection{Carbon assimilation in relation to crop growth}

Carbon assimilation for corn and soybean was directly connected to plant growth parameters, confirming that both crops were the main influencing factor on the carbon balance of the agroecosystems. Similar findings were previously reported where grain crops were identified as major sinks of carbon (Gilmanov et al., 2013). Thereby, corn and soybean NEP increased with vegetative plant growth and decreased when reaching plant senescence. In addition, NEP was related to LAI, and hence, to the leaves as the main organs of carbon uptake. Yet, the two crops performed differently in carbon uptake: soybean carbon assimilation exceeded heterotrophic respiration at a considerably later plant development stage, and eventually declined with beginning plant senescence and leaf abscission. In contrast, carbon assimilation of corn started from an early stage of plant development, and decreased after the onset of total plant senescence; thus, carbon assimilation rapidly exceeded overall heterotrophic respiration (Fig. 3).

\section{((Figure 3; single column))}

\subsection{Light use and water use efficiency}

IWUE* determines the amount of carbon assimilated (GPP) per unit of water transpired (VPD/ET) by the plant at the ecosystem level (Beer et al., 2009). In addition, the LUE determines the amount of carbon assimilated per unit of radiation intercepted. The average IWUE* and LUE followed the overall trend for 
carbon uptake of each agro-ecosystem. IWUE* and LUE decreased in the following order corn > prairie > soybean (Fig. 2, Fig. 4). Thus, corn was the most efficient in water and radiation use for carbon assimilation. Corn is a $\mathrm{C}_{4}$ plant, where the protein PEP-Carboxylase is used in its carbon assimilation pathway, which is very efficient in deriving carbon metabolites from $\mathrm{CO}_{2}$. In contrast, soybean as a $\mathrm{C}_{3}$ plant (meaning that the protein Rubisco is used in its carbon assimilation pathway), was least effective in carbon uptake. Values of IWUE* and LUE were within typical ranges of cropland in the Midwest (Turner et al. 2003, Xin et al., 2014) or elsewhere (Beer et al., 2009). The efficiency of prairie vegetation to assimilate carbon was lower than in corn, but higher than soybean. The studied tallgrass prairie site was dominated by $\mathrm{C}_{4}$ plants (Martin et al., 2005), which probably improved the overall carbon assimilation of the ecosystem. In addition, a reconstructed prairie site was investigated in this study, and the efficiency to assimilate or store carbon may differ to native prairie remnants. That limits the direct comparison to other prairie sites, and previous studies report higher LUEs in tallgrass prairie (Turner et al., 2003) or found strong differences of water use efficiency among prairie sites (Wagle et al., 2015).

\section{((Figure 4; single column))}

\subsection{Impact of environmental factors on carbon uptake}

In this study, the impact of temperature, VWC and precipitation on carbon assimilation of different agroecosystems was investigated during a long-term period with contrasting weather conditions. Previous results from the same corn and soybean sites suggested, that warm-wet years diminish NEP of cropland, and colder-wetter years increases NEP due to lower respiration losses (Hernandez et al., 2011). Yet another study found, that NEP of the Midwest region increased in warm-wet years, while it decreased in warm-dry years (Lu and Zhuang, 2010). Also GPP in North America decreased, where air temperature rise and precipitation decreased (Mekonnen et al., 2016). 


\section{((Figure 5; single column))}

This is partly in contrast to results of this study, where higher air temperature improved IWUE*, LUE or GPP of three agro-ecosystems even though prairie and cropland were affected differently by rainfall. An increase in air temperature can reportedly increase GPP in cooler climates due to improved carboxylation rates, higher N-mineralization and a prolonged growing season. A decrease of GPP due to a rise in air temperature can be attributed to warmer climates because of the increased VPD, which has an adverse effect on stomatal conductance and eventually $\mathrm{CO}_{2}$ assimilation. In addition, $\mathrm{Reco}_{\text {eco }}$ may increase due to enhanced autotrophic respiration (Mekonnen et al., 2016). In this study, NEP increased with $T_{\max }$ at all three sites, which suggests increased carbon assimilation with rising temperatures, while the negative trend of $R_{\text {eco }}$ and $T_{\max }$ reflect increased auto- and heterotrophic respiration. Both, NEP and $R_{\text {eco }}$ increase GPP, and hence LUE and IWUE*.

\section{((Figure 6; single column))}

In addition, the GPP or IWUE* decreased with increasing rainfall or VWC in both corn and soybean. The negative correlation of NEP to rainfall or VWC in corn and soybean suggest a suppression of carbon assimilation, while $R_{\text {eco }}$ did not change. Hence, the increase in precipitation mainly affected NEP and eventually decreased GPP, IWUE* and LUE. The combined effect of precipitation and temperature would suggest that carbon assimilation of corn and soybean is negatively affected in cold-wet years, while a positive effect in warm-dry years can be expected.

GPP and NEP are partially positively correlated with precipitation on a global (Beer et al., 2010) or regional (Lu and Zhuang, 2010) scale. Yet, the observed trend of reduced GPP under high rainfall for cropland is most likely connected to the seasonal distribution of rainfall and local soil conditions. Soils of the studied cropland area have a clay loam texture, are partly poorly drained with a naturally high water table (DeWitt, 1984). Thus, high precipitation may easily lead to water-logged soil conditions in the studied area, despite the installed subsurface drainage system. 


\section{((Figure 7; single column))}

An average GS VWC up to $41 \%$ was measured in the upper $10 \mathrm{~cm}$ soil profile on cropland (Fig. 7), thus, probably experiencing water-logged conditions in the subsoil. Water logging reportedly causes stomata closure and reduction of net photosynthesis in higher plants (Terazawa et al., 1992, Jackson and Hall, 1987), and affects the growth of corn and soybean (Evans et al., 1990). Both, the reduction of GPP and water use efficiency due to water logging was previously recognized in boreal forests (Ohta et al., 2014), and predictions for the Midwest area assume higher spring rainfall and water-logging due to climate change, eventually affecting crop yield (Rosenzweig et al., 2002, Wuebbles and Hayhoe, 2004, Li et al., 2011). In addition, when spring precipitation is high as it was in 2013 , farmers tend to plant late, as for instance soybean was planted at DOY 171, leading to the lowest annual GPP and NEP observed (Fig. A.2). In that year, the carbon loss by heterotrophic respiration was highest and exceeded carbon gain by assimilation of the crop. In contrast, the negative effect of climate change on crop performance in the Midwest is less pronounced under warm-dry conditions (Li et al., 2011), which is in agreement with this study. However, a sequence of several dry years would probably deplete the soil water storage, and adverse effects of air temperature or rainfall may occur. Lu and Zhuang (2010) found the lowest net primary production in extreme drought years with high temperatures and low precipitation in the entire Midwest. In addition, a steady increase of air temperature, as it has been recognized for the past decades, will eventually decrease GPP, when a certain threshold is reached (Mekonnen et al., 2016). Furthermore, parts of the Midwest region are differently affected, which is adhered to a natural gradient of precipitation and temperature (Hernandez et al., 2011). For example, corn GPP declined and tallgrass prairie GPP was not affected or slightly increased during the drought periods of 2011 and 2012 in Central Illinois (Joo et al., 2014; Hussain et al., 2013), while no such effect was found in this study. 


\section{((Figure 8; single column))}

Contrasting effects were found in the reconstructed tallgrass prairie, where GPP and LUE increased with rainfall or VWC, while IWUE* declined. Drought stress causes stomata closure, which eventually adversely affects carbon assimilation. Petrie et al. (2016) stated that precipitation variability influences grassland carbon dynamics. Wagle et al. (2015) reported that prairie vegetation without rainfall $>600 \mathrm{~mm}$ have a neutral carbon balance or small carbon emissions. Gilmanov et al. (2005) suggested that grasslands may switch from carbon sinks to sources when rainfall holds off. In this study, we could confirm such trend for a long-term dataset including wet and dry years. The studied tallgrass prairie acted as a carbon sink throughout the nine year period with the lowest annual precipitation of $600 \mathrm{~mm}$ in 2012. Previous findings also concluded that the water use efficiency decreased in dry years in prairie vegetation (Wagle et al., 2015), and severe drought events have reduced GPP and IWUE* of temperate grasslands (Hussain et al., 2011). A reduction of IWUE* with VWC, connected with a positive relation of VPD was previously reported from Eamus et al. (2013). For example, in 2012 (dry year) maximum IWUE* and VPD was 50.8 g C * hPa $\mathrm{kg} \mathrm{H}_{2} \mathrm{O}^{-1}$ and $31 \mathrm{hPa}$, while in 2008 (wet year) IWUE* and VPD reached highest values of $36.9 \mathrm{~g} \mathrm{C} * \mathrm{hPa} \mathrm{kg}$ $\mathrm{H}_{2} \mathrm{O}^{-1}$ and $18 \mathrm{hPa}$, respectively. Annual GPP was 1001 and $800 \mathrm{~g} \mathrm{C} \mathrm{m}^{-2} \mathrm{yr}^{-1}$ in 2008 and 2012, respectively. The advantage of IWUE* is that it accounts for the impact of VPD on water use efficiency. The increase of IWUE* due to high VPD is based on the regulation of stomates, which restrict transpiration more than $\mathrm{CO}_{2}$ uptake (Jongen et al., 2011). Note that a native prairie may be more adapted to dry-cold conditions than the studied relatively young reconstructed site, which eventually may have impacted carbon uptake. Yet, IWUE* decreased with high rainfall at all sites, either due to a reduction in GPP under wet conditions (corn and soybean), or the increase in VPD under dry conditions (prairie). The amount and efficiency of carbon assimilation of tallgrass prairie and cropland were differently affected by precipitation or soil water. While GPP and LUE of tallgrass prairie decreased with VWC and rainfall, GPP, LUE or IWUE* on cropland was diminished by excessive precipitation and water logging. 


\section{((Figure 9; single column))}

\section{Conclusion}

The Midwest region in the US is one of the most important crop production areas for corn and soybean, but also comprises remnants of original tallgrass prairie vegetation. Predictions assume a negative impact of climate change on the region, either by the abundance or the lack of precipitation or increasing temperatures. In this study, three agro-ecosystems (corn, soybean and tallgrass prairie) were investigated in central lowa from 2006 - 2015. This period of time had contrasting weather conditions. GPP and NEP were highest in corn and lowest in soybean, related to the vegetation's efficiency to use water (IWUE*) and radiation (LUE) for carbon assimilation. Tallgrass prairie vegetation assimilated and stored more carbon than a soybean agro-ecosystem. Soybeans assimilated and stored low amounts of carbon, and heterotrophic respiration losses were highest during the long fallow period. Also the corn agro-ecosystem showed higher heterotrophic respiration of carbon than prairie vegetation during the off season. However, corn assimilated and stored the highest amounts of carbon during the growing season, which ameliorated the annual carbon balance. Yet, the corn-soybean agroecosystem acted as a carbon source due to yield removal. Air temperature significantly increased GPP, IWUE* or LUE in corn and soybeans. In addition, GPP or IWUE* of cropland were negatively affected by excessive precipitation or high VWC, probably due to water-logged soil conditions. Both individual analyses suggest that carbon assimilation of corn and soybeans increases in dry-warm years and decreases in wet-cold years. GPP, IWUE* or LUE of tallgrass prairie increased with precipitation, high VWC and air temperature, suggesting that warm-wet years ameliorate carbon assimilation and dry-cold years have adverse effects on carbon uptake. 


\section{Acknowledgement}

This research was supported in part by an appointment to the Agricultural Research Service (ARS) Research Participation Program administered by the Oak Ridge Institute for Science and Education (ORISE) through an interagency agreement between the U.S. Department of Energy (DOE) and the U.S. Department of Agriculture (USDA). ORISE is managed by ORAU under DOE contract number DE-AC0506OR23100. All opinions expressed in this paper are the author's and do not necessarily reflect the policies and views of USDA, ARS, DOE, or ORAU/ORISE. The authors wish to thank Cynthia Cambardella for her suggestions. 


\section{References}

Allen, R.G., Pruitt, W.O., 1991. FAO-24 Reference Evapotranspiration Factors. Journal of Irrigation and Drainage Engineering, 758-773.

Allen, R.G., Pereira, L.S., Raes, D., Smith, M., 1998. Crop evapotranspiration-Guidelines for computing crop water requirements - FAO Irrigation and drainage paper 56. FAO, Rome 300, D05109.

Baker, J., Griffis, T., 2005. Examining strategies to improve the carbon balance of corn/soybean agriculture using eddy covariance and mass balance techniques. Agricultural and Forest Meteorology 128, 163-177.

Beer, C., Ciais, P., Reichstein, M., Baldocchi, D., Law, B., Papale, D., Soussana, J.F., Ammann, C., Buchmann, N., Frank, D., 2009. Temporal and among-site variability of inherent water use efficiency at the ecosystem level. Global Biogeochemical Cycles 23, 1-13.

Beer, C., Reichstein, M., Tomelleri, E., Ciais, P., Jung, M., Carvalhais, N., Rödenbeck, C., Arain, M.A., Baldocchi, D., Bonan, G.B., 2010. Terrestrial gross carbon dioxide uptake: global distribution and covariation with climate. Science 329, 834-838.

Campbell, G., Norman, J.M., 1998. An introduction to environmental biophysics. Springer, New York, USA, p. 286.

Chi, J., Waldo, S., Pressley, S., O’Keeffe, P., Huggins, D., Stöckle, C., Pan, W.L., Brooks, E., Lamb, B., 2016. Assessing carbon and water dynamics of no-till and conventional tillage cropping systems in the inland Pacific Northwest US using the eddy covariance method. Agricultural and Forest Meteorology 218, 37-49.

DeWitt, T.A., 1984. Soil survey of Story County, lowa. USDA Soil Conservation Service, Washington, D.C, p. 149. 
Eamus, D., Cleverly, J., Boulain, N., Grant, N., Faux, R., Villalobos-Vega, R., 2013. Carbon and water fluxes in an arid-zone Acacia savanna woodland: An analyses of seasonal patterns and responses to rainfall events. Agricultural and Forest Meteorology 182, 225-238.

Evans, R., Skaggs, R., Sneed, R., 1990. Normalized crop susceptibility factors for corn and soyabean to excess water stress. Transactions of the ASAE 33, 1153-1161.

Evans, S.P., Knezevic, S.Z., Lindquist, J.L., Shapiro, C.A., 2003. Influence of nitrogen and duration of weed interference on corn growth and development. Weed Science 51, 546-556.

Food and Agriculture Organization of the United Nations (FAO), (FAO Statistical Databases, Rome, 2013); http:// faostat.fao.org, data acquired: 11/13/2015.

Gilmanov, T.G., Verma, S.B., Sims, P.L., Meyers, T.P., Bradford, J.A., Burba, G.G., Suyker, A.E., 2003. Gross primary production and light response parameters of four Southern Plains ecosystems estimated using long-term CO2-flux tower measurements. Global Biogeochemical Cycles 17, 1071, doi:10.1029/2002GB002023, 2.

Gilmanov, T.G., Tieszen, L.L., Wylie, B.K., Flanagan, L.B., Frank, A.B., Haferkamp, M.R., Meyers, T.P., Morgan, J.A., 2005. Integration of $\mathrm{CO}_{2}$ flux and remotely-sensed data for primary production and ecosystem respiration analyses in the Northern Great Plains: potential for quantitative spatial extrapolation. Global Ecology and Biogeography 14, 271-292.

Gilmanov, T., Soussana, J., Aires, L., Allard, V., Ammann, C., Balzarolo, M., Barcza, Z., Bernhofer, C., Campbell, C., Cernusca, A., 2007. Partitioning European grassland net ecosystem $\mathrm{CO}_{2}$ exchange into gross primary productivity and ecosystem respiration using light response function analysis. Agriculture, Ecosystems \& Environment 121, 93-120. 
Gilmanov, T.G., Wylie, B.K., Tieszen, L.L., Meyers, T.P., Baron, V.S., Bernacchi, C.J., Billesbach, D.P., Burba, G.G., Fischer, M.L., Glenn, A.J., 2013. $\mathrm{CO}_{2}$ uptake and ecophysiological parameters of the grain crops of midcontinent North America: Estimates from flux tower measurements. Agriculture, Ecosystems \& Environment 164, 162-175.

Grünwald, T., Bernhofer, C., 2007. A decade of carbon, water and energy flux measurements of an old spruce forest at the Anchor Station Tharandt. Tellus B 59, 387-396.

Guanter, L., Zhang, Y., Jung, M., Joiner, J., Voigt, M., Berry, J.A., Frankenberg, C., Huete, A.R., Zarco-Tejada, P., Lee, J.-E., 2014. Global and time-resolved monitoring of crop photosynthesis with chlorophyll fluorescence. Proceedings of the National Academy of Sciences 111, E1327-E1333.

Hernandez-Ramirez, G., Hatfield, J.L., Prueger, J.H., Sauer, T.J., 2010. Energy balance and turbulent flux partitioning in a corn-soybean rotation in the Midwestern US. Theoretical and applied climatology 100, 79-92.

Hernandez-Ramirez, G., Hatfield, J.L., Parkin, T.B., Sauer, T.J., Prueger, J.H., 2011. Carbon dioxide fluxes in corn-soybean rotation in the Midwestern US: Inter-and intra-annual variations, and biophysical controls. Agricultural and Forest Meteorology 151, 1831-1842.

Hussain, M., Grünwald, T., Tenhunen, J., Li, Y., Mirzae, H., Bernhofer, C., Otieno, D., Dinh, N., Schmidt, M., Wartinger, M., 2011. Summer drought influence on $\mathrm{CO}_{2}$ and water fluxes of extensively managed grassland in Germany. Agriculture, Ecosystems \& Environment 141, 67-76.

Hussain, M., Zeri, M., Bernacchi, C., 2013. The impact of extreme drought on the biofuel feedstock production. AGU Fall Meeting Abstracts, p. 0602.

lowa Environmental Mesonet, 2014. http://mesonet.agron.iastate.edu; data acquired: 2014/2015 
Jackson, M., Hall, K., 1987. Early stomatal closure in waterlogged pea plants is mediated by abscisic acid in the absence of foliar water deficits. Plant, Cell \& Environment 10, 121-130.

Jenkins, J., Richardson, A., Braswell, B., Ollinger, S., Hollinger, D., Smith, M.-L., 2007. Refining light-use efficiency calculations for a deciduous forest canopy using simultaneous tower-based carbon flux and radiometric measurements. Agricultural and Forest Meteorology 143, 64-79.

Jongen, M., Pereira, J.S., Aires, L.M.I., Pio, C.A., 2011. The effects of drought and timing of precipitation on the inter-annual variation in ecosystem-atmosphere exchange in a Mediterranean grassland. Agricultural and Forest Meteorology 151, 595-606.

Joo, E., Hussain, M., Zeri, M., Masters, M., Gomez-Casanovas, N., DeLucia, E., Bernacchi, C., 2014. How Seasonal Drought Affect Carbon and Water Fluxes of Alternative Energy Crops in the US? , AGU Fall Meeting Abstracts, p. 06.

Li, X., Takahashi, T., Suzuki, N., Kaiser, H.M., 2011. The impact of climate change on maize yields in the United States and China. Agricultural Systems 104, 348-353.

Lloyd, J., Taylor, J., 1994. On the temperature dependence of soil respiration. Functional Ecology, 315323.

Lobo, F.d.A., de Barros, M., Dalmagro, H., Dalmolin, Â., Pereira, W., de Souza, É., Vourlitis, G., Ortíz, C.R., 2013. Fitting net photosynthetic light-response curves with Microsoft Excel-a critical look at the models. Photosynthetica 51, 445-456.

Lu, X., Zhuang, Q., 2010. Evaluating climate impacts on carbon balance of the terrestrial ecosystems in the Midwest of the United States with a process-based ecosystem model. Mitigation and Adaptation Strategies for Global Change 15, 467-487. 
Maher, R.M., Asbjornsen, H., Kolka, R.K., Cambardella, C.A., Raich, J.W., 2010. Changes in soil respiration across a chronosequence of tallgrass prairie reconstructions. Agriculture, Ecosystems \& Environment 139, 749-753.

Martin, L.M., Moloney, K.A., Wilsey, B.J., 2005. An assessment of grassland restoration success using species diversity components. Journal of Applied Ecology 42, 327-336.

Mekonnen, Z.A., Grant, R.F., Schwalm, C., 2016. Contrasting changes in gross primary productivity of different regions of North America as affected by warming in recent decades. Agricultural and Forest Meteorology 218, 50-64.

Moffat, A.M., Papale, D., Reichstein, M., Hollinger, D.Y., Richardson, A.D., Barr, A.G., Beckstein, C., Braswell, B.H., Churkina, G., Desai, A.R., 2007. Comprehensive comparison of gap-filling techniques for eddy covariance net carbon fluxes. Agricultural and Forest Meteorology 147, 209-232.

Moore, C.J., 1986. Frequency response corrections for eddy correlation systems. Boundary-Layer Meteorology 37, 17-35.

Ort, D.R., Long, S.P., 2014. Limits on yields in the Corn Belt. Science 344, 484-485.

Petrie, M.D., Brunsell, N.A., Vargas, R., Collins, S.L., Flanagan, L.B., Hanan, N.P., Litvak, M.E., Suyker, A.E., 2016. The sensitivity of carbon exchanges in Great Plains grasslands to precipitation variability. Journal of Geophysical Research: Biogeosciences 121, 280-294.

Reichstein, M., Falge, E., Baldocchi, D., Papale, D., Aubinet, M., Berbigier, P., Bernhofer, C., Buchmann, N., Gilmanov, T., Granier, A., 2005. On the separation of net ecosystem exchange into assimilation and ecosystem respiration: review and improved algorithm. Global Change Biology 11, 1424-1439. 
Robertson, K.R., Anderson, R.C., Schwartz, M.W., 1997. The tallgrass prairie mosaic. In: Schwartz, M.W. (ed.), 1997. Conservation in highly fragmented landscapes. Chapman \& Hall, New York, USA, pp. 55-87.

Rosenzweig, C., Tubiello, F.N., Goldberg, R., Mills, E., Bloomfield, J., 2002. Increased crop damage in the US from excess precipitation under climate change. Global Environmental Change 12, 197-202.

Roxburgh, S., Berry, S., Buckley, T., Barnes, B., Roderick, M., 2005. What is NPP? Inconsistent accounting of respiratory fluxes in the definition of net primary production. Functional Ecology 19, 378-382.

Schilling, K., Drobney, P., 2014. Restoration of Prairie Hydrology at the Watershed Scale: Two Decades of Progress at Neal Smith National Wildlife Refuge, lowa. Land 3, 206-238.

Schmidt, M., Reichenau, T.G., Fiener, P., Schneider, K., 2012. The carbon budget of a winter wheat field: An eddy covariance analysis of seasonal and inter-annual variability. Agricultural and Forest Meteorology $165,114-126$.

Tanner, C.B.T., Thurtell G.W., 1969. Anemoclinometer Measurements of Reynolds Stress and Heat Transport in the Atmosphric Surface Layer. Wisconsin University - Madison, Department of Soil Science, $1-10$.

Terazawa, K., Maruyama, Y., Morikawa, Y., 1992. Photosynthetic and stomatal responses of Larix kaempferi seedlings to short-term waterlogging. Ecological Research 7, 193-197.

Turner, D.P., Urbanski, S., Bremer, D., Wofsy, S.C., Meyers, T., Gower, S.T., Gregory, M., 2003. A crossbiome comparison of daily light use efficiency for gross primary production. Global Change Biology 9, 383395.

United States Department of Agriculture (USDA), 2014. 2012 Census of Agriculture, lowa, State and County Data, Volume 1, Geographic Area Series, Part 15. p. 658. 
Verma, S.B., Kim, J., Clement, R.J., 1989. Carbon dioxide, water vapor and sensible heat fluxes over a tallgrass prairie. Boundary-Layer Meteorology 46, 53-67.

Vickers, D., Mahrt, L., 1997. Quality control and flux sampling problems for tower and aircraft data. Journal of Atmospheric and Oceanic Technology 14, 512-526.

Wagle, P., Xiao, X., Scott, R.L., Kolb, T.E., Cook, D.R., Brunsell, N., Baldocchi, D.D., Basara, J., Matamala, R., Zhou, Y., Bajgain, R., 2015. Biophysical controls on carbon and water vapor fluxes across a grassland climatic gradient in the United States. Agricultural and Forest Meteorology 214-215, 293-305.

Waller, S., Lewis, J., 1979. Occurrence of $C_{3}$ and $C_{4}$ photosynthetic pathways in North American grasses. Journal of Range Management, 12-28.

Webb, E., Pearman, G., Leuning, R., 1980. Correction of flux measurements for density effects due to heat and water vapour transfer. Quarterly Journal of the Royal Meteorological Society 106, 85-100.

Whitney, G.G., 1994. From coastal wilderness to fruited plain. A history of environmental change in temperate North America 1500 to the present, Chapter 11 Grassland agriculture, Cambridge University Press, Cambridge, Great Britain, p. 451.

Wuebbles, D., Hayhoe, K., 2004. Climate Change Projections for the United States Midwest. Mitigation and Adaptation Strategies for Global Change 9, 335-363.

Xin, Q., Broich, M., Suyker, A.E., Yu, L., Gong, P., 2015. Multi-scale evaluation of light use efficiency in MODIS gross primary productivity for croplands in the Midwestern United States. Agricultural and Forest Meteorology 201, 111-119. 